\title{
That's oil, folks...
}

\section{Optimists see oil gushing for decades; pessimists see the planet's energy future already drying up. Alexandra Witze reports.}

( on't say they didn't warn us. The poster for the meeting of the Association for the Study of Peak Oil and Gas in Boston this October featured American revolutionary Paul Revere on his midnight ride, bringing news of imminent calamity. Only this time it is not the British who are coming, but the end of the oil era, and with it much of western civilization. Many attendees at the meeting were people who could tell you how to stock a bunker to survive the inevitable collapse of civilization, and then opine at length about the extent and characteristics of the great tar-sand deposits of Canada. Some of them conduct a thriving mini-business in preparing for the coming apocalypse - ${ }^{\alpha} \mathrm{deal}$ with reality or reality will deal with you", as one website claims - while scrutinizing table after table of data on world oil production.

But this is not an easily dismissed fringe. Respected geologists with lifetimes of experience are genuinely concerned that the world is about to see an unprecedented crisis - a reduction in the supply of a primary fuel before an alternative is available. When we moved from wood to coal, it was not for a shortage of forests; when we moved in large part from coal to oil and gas, it wasn't because the pits were empty. But many people are convinced that the flow of oil is destined to start falling, and soon.

Matthew Simmons, an energy investment banker in Houston, Texas, and self-described "petro-pessimist", argues that the world's great oilfields are moving quickly towards the end of their production, or have already passed into rapid decline. The North Sea, for instance, is the only place that a significant new discovery has been made outside of nations in the Organization of the Petroleum Exporting Countries (OPEC), Russia and Alaska in the past four decades. It is now in eclipse - production in the region peaked in 1999, which is earlier, Simmons says, than expected. The United Kingdom no longer exports oil, he notes, and production in Norway - the North Sea's long-term stalwart - is also

"Idon't know if we
are all Hubbertists
now, but we are all
recognizing that
there is a finite
quantity of oil."
- Robert Kaufmann

If the reserves are more or less equal to the amount already pumped, then production is at its peak.

If you accept this principle, then the issue of when the peak comes depends mainly on the amount of reserves that remain untapped, and that in itself gives room for disagreement. But some don't accept these premises. To them, these arguments are simplistic geological determinism that does not take into account the role of oil prices. To the dissenters, reserves are not a geological given but a function of the current price and the extraction declining. And no new giant oilfields are taking the place of those that have already passed their peaks, says Simmons.

Some people think that the declines we are seeing are indicators that the world is on the verge of, or has already passed, the maximum amount of oil that can physically be produced. In their view, oil production follows a bellshaped trajectory, with the peak occurring when half of the total reserves have been consumed. Therefore, it should, in theory, be easy to determine whether the peak has already occurred or whether it is yet to come. Total up the world's oil reserves, estimate the rate at which countries have produced oil, and you'll know where you are in the trajectory.

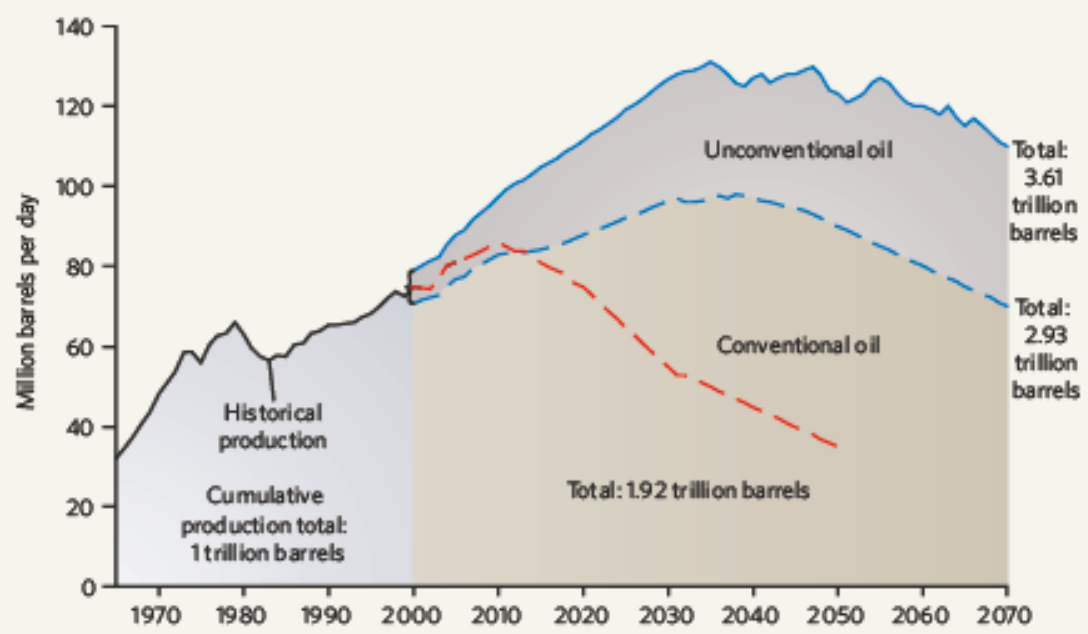

Twin peaks: peak-oil supporters think we have already reached or will soon reach a historical maximum of oil production (red line); others argue that oil production will not peak until at least 2030 (blue lines). technology that price can buy. New reserves will be developed as the market demands.

\section{Opposites attract}

Both sides issue regular, well-referenced reports that come to opposite conclusions on whether the world is running out of oil. "There's just no middle ground," says Kenneth Deffeyes, a geologist who has retired from Princeton University in New Jersey, and is a leading supporter of the peak-oil theory. His personal belief is that we are already a year past the peak. If he's wrong, though, he's sure that it will prove not to be by much: the peak is imminent, and unavoidable.

Meanwhile, a study from energy analysts Cambridge Energy Research Associates (CERA) in Massachusetts sees no sign of any peak in production occurring before 2030. And, crucially, CERA doesn't see a peak with a steep downside - rather a crest followed by an undulating plateau (see chart), which would be much less apocalyptic even if it happened today.

It's not that CERA thinks that oil production has no constraints, or that the geological resource can't be depleted. Even oil company executives say publicly that they see a problem. T. Boone Pickens, the maverick Texas oil magnate, hassaid that he thinks oil production may already have reached its maximum. And in October, during an address to the National Press Club in Washington DC, Shell Oil president John Hofmeister acknowledged that ${ }^{\alpha}$ the easy stuff is running out". "We may argue about when the peak is, but it doesn't change the argument that it's coming," says Robert Kaufmann, an energy economist at Boston University in Massachusetts. "I don't know if we are all Hubbertists now, but we are all recognizing that there is a finite quantity of oil." 
Hubbert, in this context, is M. King Hubbert, the geophysicist who first predicted that oil production would peak quite suddenly and that when it did, it would slump sharply thereafter. In 1956, while working in Shell Oil's research laboratory in Houston, Texas, Hubbert predicted ${ }^{1}$ that oil production in the contiguous 48 states of the United States would peak in the early 1970 s. Hubbert's calculations produce a bell curve to describe the rate of oil production, with a sharp rise on one side of the peak and a symmetrical drop-offon the other (see chart, overleaf).

At the time Hubbert made these calculations less than half of this two-sided curve had been seen. Oil exploration and discovery were booming, and Hubbert's prediction looked implausibly pessimistic. But he turned out to be right; production in the contiguous United States reached its peak in 1970, and almost overnight Hubbert gained his own personal fan club.

Those in favour of the peak-oil theory argue that Hubbert's methods for analyzing US oil output can also be used to analyze the global production peak. Deffeyes, known to many as the charismatic protagonist of Basin and Range, the first of John McPhee's great popular accounts of modern geology, has emerged as a particularly prominent Hubbertist. In Hubbert's Peak The Impending Oil Shortage ${ }^{2}$ and Beyond Oil: The View from Hubbert's Peak ${ }^{3}$ he used the same mathematics as Hubbert to calculate the total oil reserves worldwide that remain to be produced. With a flourish of exactitude, Deffeyes estimated that the world reached peak-oil production on 24 November 2005 . He later pushed this back - but only to 16 December of that year.

"I'm not declaring victory just yet," he says hastily. He's saving the victory announcement until he sees world production numbers drop for three years in a row. "If I'm right, it will be very transparent in five years."

\section{Changing with the times}

But not everyone buys Deffeyes' interpretations. ${ }^{\alpha}$ The technique that Hubbert used in the 1950s is simply not applicable on a global basis in 2006," argues Peter Jackson, an oil and gas analyst who works for CERA near London, UK. Jackson authored CERA's background briefing paper ${ }^{\alpha}$ Why The Peak Oil Theory Falls Down ${ }^{x}$ in November 2006.

Jackson notes that proponents of the peak-oil theory have changed their dates several times before; as production numbers come in year after year, for instance, leading peak-oil theorist Colin Campbell has postponed his estimates for the peak in all hydrocarbon production from around the turn of the millennium to 2010 . Others point out that predictions of an unavoidable slump are almost as old as the oil business; John Strong Newberry, chief geologist of the state of Ohio, was predicting that America's oil would soon be tapped out back in 1875 .

Jackson, Deffeyes and everyone else in the debate agree that nearly 1.1 trillion barrels (175 trillion litres) of oil have been produced

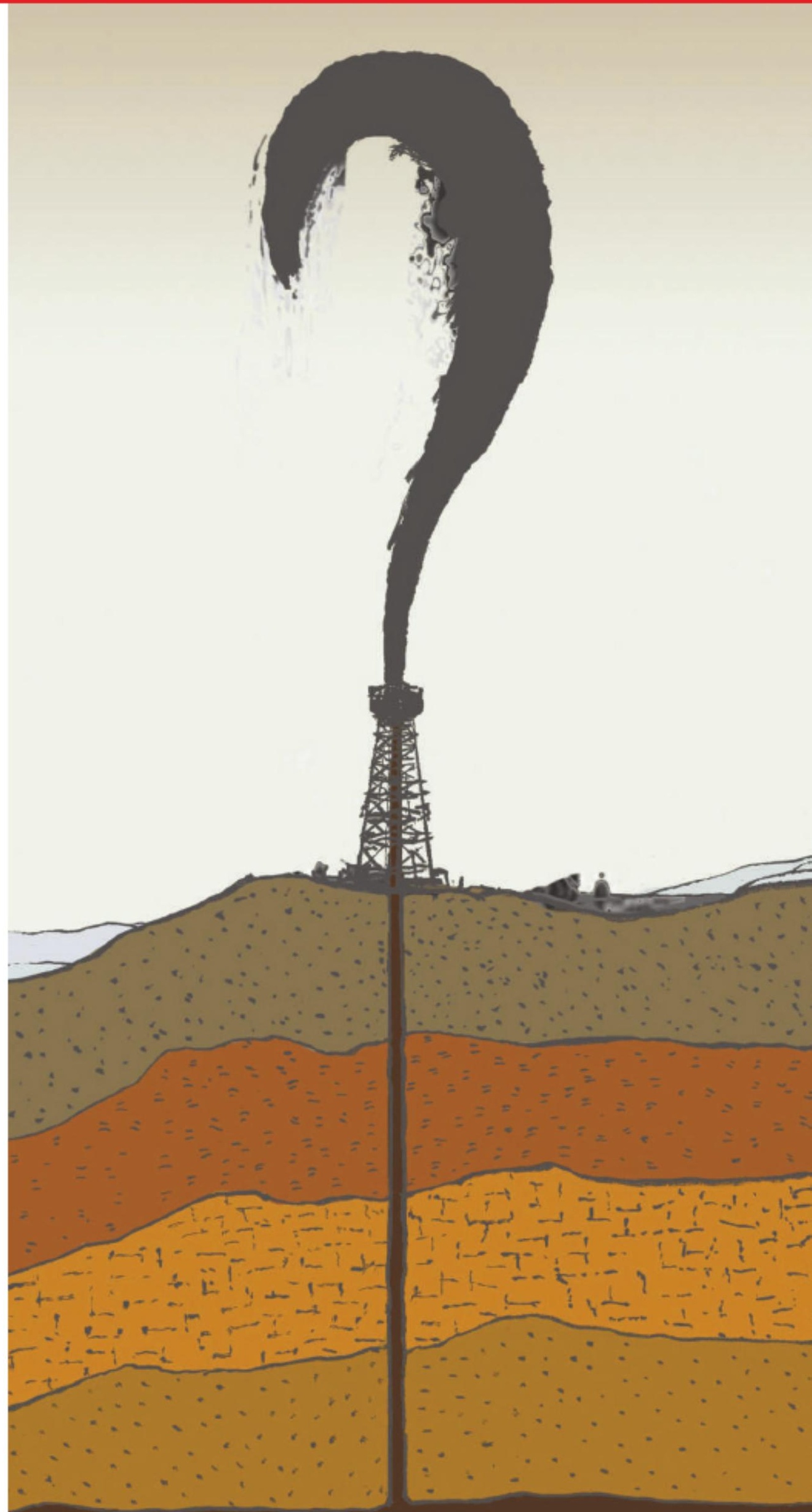


Gulf of Mexico, the amount of oil produced in the United States after the peak was much greater than Hubbert had predicted.

But the peak-oil theorists are not convinced. ${ }^{\alpha}$ The problem is, if you go and talk to people whose job it is to actually go and find this stuff, they have no clue as to where these trillion barrels of reserves actually are," says Michael Rodgers of the energy analysis firm PFC Energy in Washington DC.

\section{Who to trust?}

Estimates of reserves that are published by oil companies, national governments and researchers such as the US Geological Survey are not to be trusted, according to the peakoil supporters. Jeremy Gilbert, former chief petroleum engineer for BP, says that not all oil companies work to the same standards. The US Securities and Exchange Commission sets rules for how to report reservoir estimates, but only US and major international companies generally abide by those standards - and they don't always do so reliably. "The standards for other national companies are unknown," Gilbert says. "If someone tells you the reserves in Kuwait are 75 billion barrels, he has no idea how that 75 billion was calculated." Peak-oil supporters are eager to point out that after a sharp drop in the oil price in the mid-1980s the estimated reserves of various OPEC countries - including Iran and Iraq, which had a mutual war to finance at the time - were jacked up by their governments.

Partly as a result of such manoeuvres, Simmons is particularly pessimistic about whether OPEC nations can continue to slake the world"s thirst for oil. Currently, OPEC countries provide about $40 \%$ of the world's oil. Non-OPEC countries have been consistently producing more oil than they've been finding since the late 1980s, Rodgers told the meeting in Boston. He thinks that production from non-OPEC countries will peak between 2010 and 2015; after that, no amount of OPEC production can make up the gap between supply and the world's growing demand. The fact that such predictions have been made before does not necessarily mean that they are wrong now.

Most of the attention on OPEC focuses on Saudi Arabia, by far the biggest producer and the driver of oil prices worldwide. The country gets most of its oil from seven giant maturing oilfields. The three biggest fields have been producing oil for more than 50 years, and the oil industry constantly swirls with rumours that the biggest of all - the Ghawar field - has been increasingly cut with water to drive its production even higher. Simmons, after studying technical reports published by the Society of Petroleum Engineers, has argued that the state-run oil company Saudi Aramco routinely overestimates the country's oil reserves. Saudi Arabia, he argues, is closer to running out of oil than most people think.

The 1970s oil crisis, when OPEC slapped an embargo on countries that had supported Israel, was only a taste of things to come, says Rodgers. At the time, the United States was the only country that had already peaked in oil production. Now, many more countries - including Peru, Argentina, Norway, Congo and Mexico - have also passed their peak. Countries such as Canada, China, Brunei and Malaysia are currently undulating around a plateau of oil production and could soon decline, he predicts.

New discoveries, such as in the Mexican section of the Gulf of Mexico or in Angola or Brazil, could change the date of an imminent oil peak, says Rodgers, but only slightly. "All you can do is take the diff facing us in the next few years, and push it farther out over time. This has already happened" Fields of the size now being discovered, though, will not be large enough to push the peak back far. The 300 million barrels at Thunder Horse provide less than a week's consumption at the world"s current rate of use.

Another way Russia helped out in the 1990s, Simmons pointsout, wasbyproducingless oil than had been expected. That apparently helpful drop, though, was an exception. " [Misstated reserves] wouldn't be so bad if demand remained steady," says Simmons, "but instead it soared." The world produced $16 \%$ more oil in 2005 than it did in 1990 - and none of that production, Simmons argues, came from any major new discovery. Instead, it came from a compilation of much more incremental discoveries and increased production from a number of countries. Meanwhile, demand is expected to continue to grow as more and more families buy cars worldwide.

\section{A dipstick for the future}

Some of the oil production to meet this future demand may come from alternative approaches - extracting oil from oil shale, for example, or liquefying natural gas or coal for fuel (see Nature 444, 677-678; 2006). These 'unconventional' sources of oil are some of the reasons that the CERA outlook is so optimistic. But many of the other sources, say peak-oil supporters, are not good alternatives - certainly not the sort of thing that can easily be used in vast quantities as a replacement for sweet Saudi crude, a high-quality oil with a low sulphur content, even if the price is right. In Alberta, Canada, geologists have focused on extracting oil from tar sands which could, in theory, help supply the world's needs for decades. But the process is expensive, both financially and environmentally; three barrels of water, for instance, are needed to produce each barrel of oil from the sands, and the production releases large amounts of greenhouse gases.

Thinking along those lines raises a parallel question: can we afford, in environmental terms, to put the peak off, and to keep turning oil into atmospheric carbon dioxide at an ever- increasing rate? From an environmental point of view, a peak might almost be welcome. If the subsequent rapid drop in production crashed the world economy, though - in the way that peak-oil supporters fear - those benefits might be hard to appreciate. What's more, the resources needed to develop the alternatives on which economic recovery would depend might not be available.

Those problems might be lessened if the peak could somehow be predicted. But Kaufmann, the economist, says not to expect any financial or other indicators. Oil prices didn't rise sharply or otherwise indicate an imminent depletion of US oil resources just before the peak in 1970, he says, mainlybecause the cost of production was staying stable. To predict peak oil in advance, "you need some kind of nice price signal," he says, "and we don't see any of those signs yet."

One place to look for such signals might conceivably be in the prices for which oil is bought and sold on the futures market. And at the moment, the New York mercantile exchange is settling on prices around US $\$ 67$ a barrel. It's a price high enough to make alternative fuels interesting, but in real terms not remarkably high compared with long-term averages. If oil production does start to collapse, peak-oil supporters who want to stock their bunkers with luxury goods have the opportunity to make a killing, by buying tomorrow's oil comparatively cheap and selling it, when the time comes, much more dearly. If, that is, the time does actually come.

Alexandra Witze is Nature's Chief of Correspondents, America.

1. Hubbert, M.K. Shell Development Company Publication 95. June 1956.

2. Deffeyes, K. Hubbert's Peak: Thelmpending OI Shartoge (Princeton University Press, 2006).

3 Deffeyes, K. Beyond Oil: The Mew from Hubbert's Peak (Farrar Straus Giroux, 2006). 